Article

\title{
Mechanism of Fiscal and Taxation Policies in the Geothermal Industry in China
}

\author{
Yong Jiang ${ }^{1,2}$, Yalin $\mathrm{Lei}^{1,2, *}, \mathrm{Li} \mathrm{Li}^{1,2}$ and Jianping Ge ${ }^{1,2}$ \\ 1 School of Humanities and Economic Management, China University of Geosciences, Beijing 10083, China; \\ jiangyong@cugb.edu.cn (Y.J.); lilyght@126.com (L.L.); gejianping@cugb.edu.cn (J.G.) \\ 2 Key Laboratory of Carrying Capacity Assessment for Resources and Environment, \\ Ministry of Land and Resources, Beijing 100083, China \\ * Correspondence: leiyalin@cugb.edu.cn; Tel.: +86-10-8232-3525
}

Academic Editor: Kamel Hooman

Received: 27 May 2016; Accepted: 26 August 2016; Published: 3 September 2016

\begin{abstract}
Geothermal energy is one of the cleanest sources of energy which is gaining importance as an alternative to hydrocarbons. Geothermal energy reserves in China are enormous and it has a huge potential for exploitation and utilization. However, the development of the geothermal industry in China lags far behind other renewable energy sources because of the lack of fiscal and taxation policy support. In this paper, we adopt the system dynamics method and use the causal loop diagram to explore the development mechanism of fiscal and taxation policies in the geothermal industry. The effect of the fiscal and taxation policy on the development of the geothermal industry is analyzed. In order to promote sustainable development of the geothermal industry in China, the government should pay more attention to subsidies for the geothermal industry in the life-cycle stage of the geothermal industry. Furthermore, a plan is necessary to provide a reasonable system of fiscal and taxation policies.
\end{abstract}

Keywords: geothermal industry; fiscal and taxation policies; system dynamics; China

\section{Introduction}

As one of the cleaner sources of energy, geothermal energy is an alternative to hydrocarbons and it has gained extensive attention for this reason [1]. Although geothermal energy is usually considered as a renewable source of energy, its degree of renewability actually depends on the rate of heat extraction and regeneration. Excessive extraction of heat can accelerate the depletion, reduce reservoir productivity, and in some situations lead to the subsidence. In the absence of policies aimed at promoting sustainable use of the reservoirs for the foreseeable future it is quite possible that the thermal properties of the resource will be reduced to a level that cannot support electricity generation [2].

According to the guidelines, by the year of 2015, the geothermal heating area in China was expected to be $5 \times 10^{8} \mathrm{~m}^{2}$ and the installed capacity of geothermal power generation was hoped to reach $100 \mathrm{MW}$; the total used geothermal energy would be equivalent to the energy produced by $2 \times 10^{7}$ tons of standard coal. The utilization of geothermal resources was expected to reach $5 \times 10^{7}$ tce by 2020 [3]. It is critical for China to utilize geothermal energy for sustainable development, as China is the largest country in energy consumption and the second largest economy in the world [4,5].

Scholars have done extensive research on the technologies which affect the geothermal industry in China. They have adopted quantitative and qualitative methods to analyze the technologies and make economic assessment of the geothermal development and utilization. While the technical feasibility of geothermal energy system may be visible in most geothermal energy studies, the risk and initial investment of geothermal energy are very high and the benefits achieved by geothermal industry can not be realized until 10 to 30 years later. Meanwhile, there is no systematic policy support on 
the development and utilization of the geothermal industry. In order to promote the geothermal industry, the basic challenge is how the fiscal and taxation system affects the geothermal industry. Therefore, this paper intends to use systematic dynamics to evaluate the current fiscal and tax policies. Firstly, a review of literature concerning geothermal research and some countries' experiences with the geothermal industry are presented. Secondly, utilization of geothermal energy in China is introduced in the following section. Thereafter, the section focuses on the characteristics of effect of fiscal and taxation policies on the geothermal industry and describes the systematic dynamic model to set the model for the geothermal industry. The section of the paper analyzes the various policies affecting the geothermal industry. In the last section, some interesting conclusions and recommendations are put forth.

\section{Literature Review}

\subsection{Reviews of Geothermal Development}

In the exploration technologies literature, Darrell [6] has reviewed the advances in production engineering; over the short-,medium- and long-term, production engineering continues to play an integral part in further advancing the use of geothermal energy throughout the world. As the literature indicated, to unlock a significant fraction of this vast geothermal energy source additional major technological advances were still needed. Geophysical methods were among the three main disciplines applied to explore geothermal resources, including geology and the chemistry of thermal fluids [1,7]. Eugenio et al. [8] described a data integration tool used to identify potentially undiscovered geothermal resources in the island of Sicily. Freek et al. [9] reviewed the potential of remote sensing for exploring geothermal resources.

In the aspects of economic evaluation and sustainabilities of geothermal development, Carlos et al. [10] did an economic comparison between a traditional approach to geothermal projects and a well-head method. Liu et al. [11] compared geothermal power generation with traditional fossil fuel power and indicated the average cost of geothermal station during the life cycle which was significantly lower than that of the traditional fuel power station. Ibrahim et al. [12] analyzed the efficiency of a power station which was evaluated as follows: net electricity produced/thermal energy input. Sadiq et al. [13] reviewed the efficiencies of geothermal power plants based on the type of plant and the features of the geothermal fluid. Malafeh et al. [2] modified an economic model illustrating the application of fiscal instruments in geothermal development for electricity generation based on simplifying assumptions. Hähnlein et al. [14] and Martín-Gamboa et al. [15] stimulated sustainability and policy for the thermal use of shallow geothermal energy. The sustainable utilization of geothermal energy indicated that the geothermal energy was produced and used in a way that was compatible with the well-being of future generations and the environment. Shortall et al. [16] provided a literature review of the linkages between geothermal energy developments for electricity generation and sustainable development, as well as a review of currently available sustainability assessment frameworks.

In the issue of development policies in geothermal industry, Guan [17] pointed out that the development policies of geothermal industry were essential for the development and utilization of geothermal energy. However, she only summarized the policies in other countries. Daysh et al. [18] summarized the development of Wairakei geothermal power plant and illustrated Enactment of the Resource Management Act for development of geothermal power plant. Zhou [19] clarified the composition of geothermal industry including the business process and the organization forms of the exploitation and utilization of geothermal resources. Guo [20] summarized the investment risk of geothermal industry.

Up to now, there has been no study that systematically evaluate the fiscal and taxation policies in China. This paper fills a much needed research gap. Solving the problems of high initial investment and long payback time are imperative for the development of the geothermal industry. This paper adopts the system dynamics method, used causal loop diagram to explore the development mechanism of geothermal industry and analyzes the system of fiscal and taxation policies. Based on our 
findings, we propose policy recommendations for decision makers to establish the fiscal and taxation mechanism system.

\subsection{Government Support on Geothermal Industry}

Geothermal projects are capital-intensive and high-risk. Fiscal and taxation policies that could support the different phases of geothermal development are important to take into consideration [21]. Public mechanisms for supporting investments in geothermal energy exist at many countries. Kaneko argued that implementation of fiscal and taxation assistance such as Feed-in Tariff, tax-reduction, government subsidy for survey and construction cost would bring significant benefits both to the government and to the society. He estimated impact on electricity price if the subsidy had been issued to construction of the geothermal power plant based on Japanese model and he found that when the subsidy is granted $20 \%$ of the construction cost instead of $0 \%$, the selling price could be economized by USD 1.3 cent/kWh less [22,23].

Geothermal policy in the United States started with the California Geothermal Resources Act of 1967 and the Federal Geothermal Steam Act of 1970. The royalty structure was reduced as an added incentive as follows: for electricity production, the royalties were: $1.75 \%$ of gross proceeds for the first 10 years; $3.5 \%$ after 10 years and a portion of the fees were sent to local governments. For direct-use the royalties were: Annual fee per well between $\$ 100$ and $\$ 1000$. Federal incentives began with the Federal Energy Security Act of 1978 which included the Investment Tax Credits (ITC), followed by the Public Utility Regulatory Policy Act of 1979 (PURPA), and the Production Tax Credits (PTC). The American Recovery and Reinvestment Act of 2009 (ARRA) was funded to approximately $\$ 400$ million for a variety of geothermal projects [24].

The mechanisms of fiscal and taxation policies were established which included R\&D funding, investment aid, insurance solution, grants, contingent grant, guarantee for commercial loans, loan with redemption grant etc to lay the base for a geothermal market development in The Philippines [25,26], Australia [27], Germany and other countries [28]. In the geothermal sector, there was a predominance of investment grants, in certain cases accompanied or substituted by zero interest loans. By increasing the competitiveness of electricity produced from renewable energies, feed in tariffs and tax reduction had a positive effect on the ease with which investors could obtain fiscal support for their projects [29]. Furthermore, federal income tax, state income tax, sales tax, property tax were free in Australia. France establishes two complementary mechanisms which include research guarantees and long term productivity guarantees. The research guarantee included the cost of drilling, the pumps, and the surface equipment and fee to be paid was equal to $5 \%$ of the investment while the fee of the long term productivity guarantee was paid annually for 10 years and represents $4 \%$ of the total cost of the installation which was proved to be successful overcoming many obstacles for deployment of geothermal energy [30].

In Indonesia, Ethiopia and Kenya, the governments directly subsidized the risks in the investigation and evaluation of geothermal resources while geothermal power plants were constructed by governments and enterprises. In Peru, enterprises invested the geothermal power plant by themselves from the survey to the construction, but the risks of investment would be transferred to the governments. In Japan, government subsidies were substantially involved in the whole process of geothermal industry to promote the effective development of geothermal industry (Table 1). The governments should pay roles in improvement of accuracy in geological survey, capacity of supervision in drilling, evaluation in geothermal reservoir and its analysis. Achievements of these impacted on all the stakeholders of geothermal development [24,31].

The various mechanisms were the tools to boost the geothermal development. The fiscal and taxation policies were various from the aspect of state and local policies, technology subsidy and long-term support, subsidy of the whole life cycle of geothermal industry, subsidy for producers and consumers, feed-in tariff, tax reduction or free tax. The fiscal and taxation incentives gave the public support to dedicated to geothermal direct use and power generation and promoted to developing the geothermal industry. 
Table 1. Comparison of development stages in different countries [24,31].

\begin{tabular}{|c|c|c|c|c|c|}
\hline Country & Surface Survey & $\begin{array}{c}\text { Drilling } \\
\text { Evaluation }\end{array}$ & Plant Construction & Risk & Note \\
\hline Peru & Private & Private & Private & High & $\begin{array}{l}\text { Owner of responsibility in } \\
\text { development risks might } \\
\text { shift to the government }\end{array}$ \\
\hline Indonesia & Government & $\begin{array}{l}\text { Government; } \\
\text { Private }\end{array}$ & Private & - & - \\
\hline Kenya & Government & Government & Government; Private & Low & $\begin{array}{l}\text { At Suswa, } 300 \mathrm{MV} \text { project } \\
\text { will be conducted by a } \\
\text { private company }\end{array}$ \\
\hline Ethiopia & Government & Government & Government; Private & Low & - \\
\hline Japan & $\begin{array}{l}\text { Up to } 50 \%-100 \% \text { of } \\
\text { necessary funds (depends } \\
\text { on terms and conditions) }\end{array}$ & $\begin{array}{l}\text { Up to } 50 \% \text { of } \\
\text { equity capital }\end{array}$ & $\begin{array}{l}\text { Up to } 80 \% \text { of loan } \\
\text { provided by financial } \\
\text { institutions }\end{array}$ & Low & - \\
\hline
\end{tabular}

In order to guarantee the development of the geothermal industry, the Chinese government formulated a series of policies and regulations (Table 2). In 2002, Ministry of Land and Resources pointed out that the geothermal resources was one of the most important clean energies and the government planned to promote the geothermal industry. Implementing "Renewable Energy Law" in 2006, the government explicitly stated the importance of geothermal development and encouraged enterprises to develop the geothermal energy. After that, China attached great importance to the development and utilization of geothermal energy. China's National Energy Administration, Ministry of Finance, Ministry of Land and Resources, and Ministry of Housing and Urban-Rural Development jointly issued a document named "Guidelines on promoting of geothermal energy development and utilization" in January 2013 which was the first and complete document as an incentive for geothermal industry in China. It referred that the government should give the subsidies to the geothermal power generation.

At present, China has initially formed integrated development utilization system of geothermal energy [32]. It centers on geothermal power generation and direct use which is mainly for heating and cooling, spa treatment, tourism, agriculture, etc. Geothermal power generation can be divided into conventional power generation and enhanced geothermal systems (EGS) power generation. Conventional type in China usually divided into high temperature(above $150^{\circ} \mathrm{C}$ ) geothermal power generation and low-medium temperature geothermal power generation. Direct use of geothermal energy mainly be divided into heating and cooling of low-medium temperature geothermal energy which includes district heating, air-conditioning, greenhouse heating and industrial process heat and hot springs of shallow geothermal energy which includes bathing and swimming utilization. As to geothermal power generation and direct-use, China Academy of Engineering put forward the development goals in different time nodes (Table 3). As can be seen in Table 3, up to 2050, the scale of the low-medium temperature geothermal direct-use will triple the current value, and the shallow geothermal energy utilization can reach 50,000 MWt. The high temperature power installed generation capacity will be promoted, and stress will also be put on the development of the low-medium temperature and the EGS power generation [32].

However, there was no practical support policy to subsidize the manufacturer or producers of geothermal industry and fiscal and taxation policies of geothermal industry in China still existed the problems in our country. The form of fiscal support was excessively single. Throughout current fiscal policies of geothermal industry in our country, the government had not yet established various supporting policies system. Meanwhile, China lack specific subsidy policies aiming at the process of exploration and development, technical research, and consumption and long term subsidy for geothermal industry. The taxation issues of geothermal industry in our country mainly were considered from three aspects of circulation tax, resource tax, corporate income tax. Up to now, our tax standards of geothermal industry was still applicable to natural resources standards. 
Table 2. Policy and regulations for China's Geothermal industry [32,33].

\begin{tabular}{|c|c|c|c|}
\hline No. & Law or Regulation & Time & Contents \\
\hline 1 & $\begin{array}{l}\text { Notice of the Ministry of land and resources on } \\
\text { Further Strengthening the geothermal mineral water } \\
\text { resources management }\end{array}$ & December 2002 & $\begin{array}{l}\text { The geothermal resource is a valuable mineral resource as one of the important clean energy. } \\
\text { Promotes the survey geothermal resources exploration; strengthen the development and } \\
\text { utilization of geothermal resources and protection; develops geothermal projects and ground } \\
\text { water recharge to realize the sustainable utilization of geothermal resources }\end{array}$ \\
\hline 2 & Guidelines of Renewable energy industry development & November 2005 & $\begin{array}{l}\text { Lists geothermal power generation, geothermal heat pump as the key projects and geothermal } \\
\text { drilling equipment as the recommended device }\end{array}$ \\
\hline 3 & Renewable energy law & January 2006 & $\begin{array}{l}\text { Lists geothermal energy development and utilization into the scope of encouraged new } \\
\text { energy development }\end{array}$ \\
\hline 4 & $\begin{array}{l}\text { National Long-term Scientific and Technological } \\
\text { Development Plan (2006-2020) }\end{array}$ & December 2005 & Promotes development and utilization of geothermal energy as a key field \\
\hline 5 & Technical code for ground source heat pump systems & January 2006 & $\begin{array}{l}\text { Provides specification for the design, construction and acceptance of ground source heat pump } \\
\text { system projects and ensuring safe and reliable system operation }\end{array}$ \\
\hline 6 & Land and resources "eleven five year" plan & April 2006 & $\begin{array}{l}\text { Increases the intensity of mineral resources exploration, carries out geothermal hot dry rock } \\
\text { resources potential evaluation, and designs the prospective development zone }\end{array}$ \\
\hline 7 & The decision of the state council on energy saving & August 2006 & $\begin{array}{l}\text { Proposes to make great efforts in the development of renewable energy source, including wind, } \\
\text { solar, biomass, geothermal and water energy }\end{array}$ \\
\hline 8 & $\begin{array}{l}\text { Interim Measures for the administration of special funds for the } \\
\text { development of renewable energy }\end{array}$ & August 2006 & $\begin{array}{l}\text { Strengthens the management of special funds for renewable energy development, focuses on } \\
\text { supporting the development and utilization of fuel ethanol, biomass, solar energy, wind energy } \\
\text { and geothermal energy; focus on the application of solar energy, geothermal energy } \\
\text { in buildings }\end{array}$ \\
\hline 9 & $\begin{array}{l}\text { Notice of the ministry of construction and the ministry of } \\
\text { finance on the implementation comments for application of } \\
\text { renewable energy in building }\end{array}$ & August 2006 & Lists ground source heat pump application among key technological fields \\
\hline 10 & $\begin{array}{l}\text { Comprehensive working program on energy saving and } \\
\text { emission reduction }\end{array}$ & June 2007 & $\begin{array}{l}\text { States that the energy structure adjustment and the scientific research development and } \\
\text { construction of building integrated with geothermal energy shall be actively promoted, and } \\
\text { the resource investigation and assessment shall be enhanced }\end{array}$ \\
\hline 11 & Chinese National Climate Change Program & June 2007 & $\begin{array}{l}\text { Points out that the promotion and protection of water resources to meet the environmental } \\
\text { requirements of the geothermal heating and ground source heat pump technology }\end{array}$ \\
\hline 12 & National Renewable Energy Long-Term Planning & September 2007 & $\begin{array}{l}\text { Puts forward to promote large-scale application of solar energy and geothermal energy } \\
\text { in buildings }\end{array}$ \\
\hline 13 & Ordinance on civil-building energy conservation & August 2008 & States that China encourages and supports geothermal energy application \\
\hline 14 & $\begin{array}{l}\text { Notice on the promotion of shallow geothermal energy } \\
\text { development and utilization }\end{array}$ & December 2008 & $\begin{array}{l}\text { Makes deployment for the promotion of survey assessment, development and utilization } \\
\text { planning and monitoring of shallow geothermal resources }\end{array}$ \\
\hline 15 & $\begin{array}{l}\text { Scheme of "Twelfth Five Year" comprehensive energy-saving } \\
\text { emission reduction work }\end{array}$ & August 2011 & $\begin{array}{l}\text { Adjusts energy structure to develop wind energy, solar energy, geothermal energy and other } \\
\text { renewable energy }\end{array}$ \\
\hline 15 & "Twelfth Five-Year Plan" in renewable energy development & August 2012 & $\begin{array}{l}\text { Promotes the reasonable development and utilization of geothermal energy, and points out to } \\
\text { construct the key geothermal projects for electricity and direct use }\end{array}$ \\
\hline 16 & National "Twelve Five-Year" energy plan & January 2013 & Increase proportion of geothermal energy use in buildings \\
\hline 17 & $\begin{array}{l}\text { Guidelines on promoting of geothermal energy development } \\
\text { and utilization }\end{array}$ & January 2013 & $\begin{array}{l}\text { Sets a goal for geothermal energy development and utilization in } 2015 \text { and 2020, refers to the } \\
\text { key tasks and subsidy policies }\end{array}$ \\
\hline
\end{tabular}


Table 3. Strategic targets of geothermal energy development in China $[3,32]$.

\begin{tabular}{cccccc}
\hline \multirow{2}{*}{ Year } & \multicolumn{2}{c}{ Power Generation Energy Development/MWe } & \multicolumn{2}{c}{ Direct Use/MWt } \\
\cline { 2 - 6 } & $\begin{array}{c}\text { High } \\
\text { Temperature }\end{array}$ & $\begin{array}{c}\text { Low-Medium } \\
\text { Temperature }\end{array}$ & EGS & $\begin{array}{c}\text { Low-Medium } \\
\text { Temperature }\end{array}$ & $\begin{array}{c}\text { Shallow } \\
\text { Geothermal }\end{array}$ \\
\hline 2020 & 75 & 2.5 & Experiment & 4000 & 10,000 \\
2030 & 200 & 20 & 25 & 6500 & 20,000 \\
2050 & 500 & 100 & 200 & 10,000 & 50,000 \\
\hline
\end{tabular}

Fiscal and taxation policies did not match the purpose of this approach that our country put geothermal industry into the national strategic emerging industry [34] and it was difficult to achieve profitability for enterprises and consumers to promote the geothermal industry. If there were no corresponding preferential policies, the development of the geothermal industry would be severely hampered.

\section{Utilization of Geothermal Resources in China}

China produced approximately $27.32 \%$ of the world's total carbon dioxide $\left(\mathrm{CO}_{2}\right)$ emissions in 2015 (BP, 2016). This may be attributed to China's enormous use of fossil fuels, particularly coal [35]. In 2015, China's consumption of primary coal, oil, and natural gas reached $1.92 \times 10^{9}, 5.60 \times 10^{8}$ and $1.78 \times 10^{8}$ tonnes oil equivalent. In contract, renewable consumption was $6.27 \times 10^{7}$ tonnes oil equivalent. From 1980 to 2015, coal was the source of energy with the largest growth while the use of oil and natural gas also had considerable growth followed by renewable energy (Figure 1) [36]. Carbon dioxide emissions in China, which reached $9.15 \times 10^{9}$ tonnes carbon dioxide, had a similar trend as coal consumption. The values of average greenhouse gas emissions for power generation technologies have been calculated and they are $1004 \mathrm{CO}_{2}$ equivalent $\mathrm{g} / \mathrm{kWh}, 543 \mathrm{CO}_{2}$ equivalent $\mathrm{g} / \mathrm{kWh}$, and $170 \mathrm{CO}_{2}$ equivalent $\mathrm{g} / \mathrm{kWh}$ respectively for coal, gas and geothermal energy [37]. Meanwhile, the geothermal industry has positive impacts on poverty, the atmosphere, economic development, etc. It could increase the social development initiatives, displace greenhouse gas emissions from other energy sources, increase energy security and direct, indirect and induced economic activities and employment [16]. This indicates that the geothermal industry has positive environmental and social aspect effects and the government should promote clean the geothermal industry to lower the carbon emissione and enhance sustainability in China.

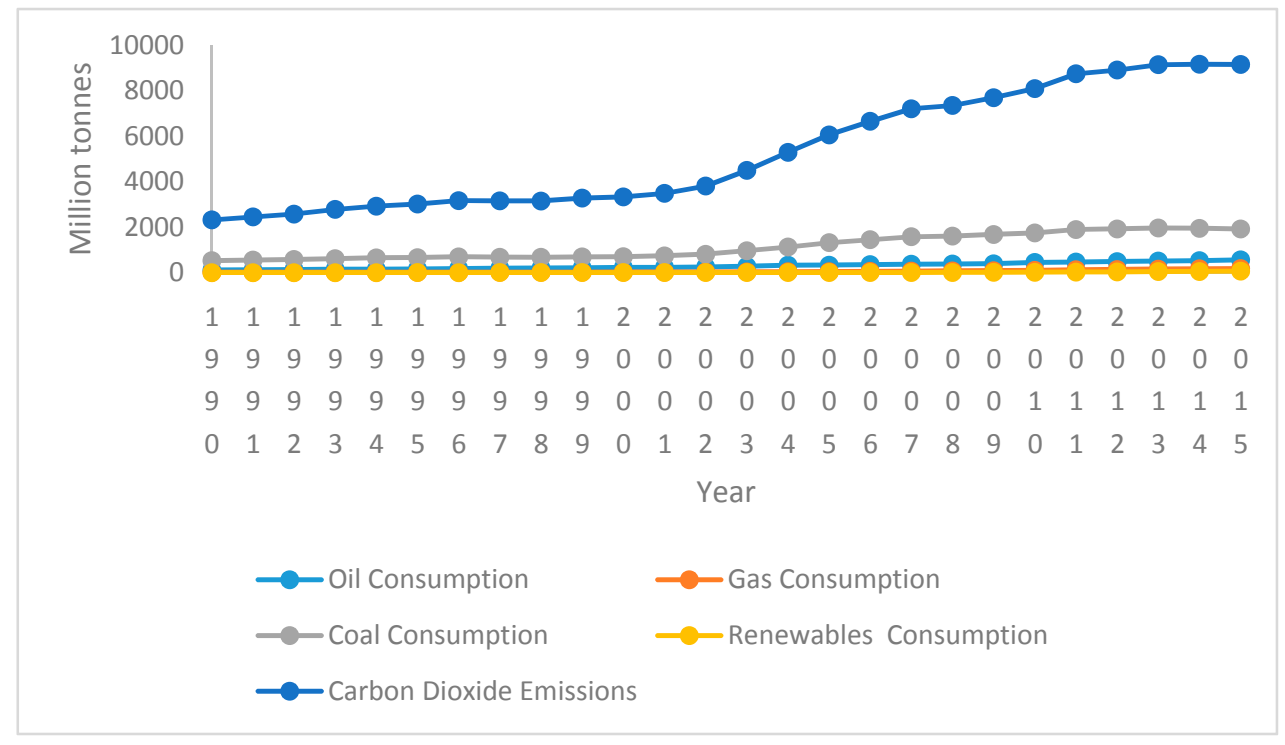

Figure 1. Energy consumption and carbon dioxide emissions from 1980 to 2015 in China. 
China has rich geothermal resources, with a value of $3.06 \times 10^{18} \mathrm{kWh} /$ year, accounting for $7.9 \%$ of the total global geothermal energy reserves [25,38,39]. From 2009 to 2011, the Ministry of Land and Resources reappraised the shallow geothermal energy of more than 287 local cities, the geothermal resources of 12 main sedimentary basin sand and 2562 apophysis mountains in hot spring areas, as well as hot dry rock resources at depths of 3-10 km [26]. The shallow geothermal resources approach $7.71 \times 10^{13} \mathrm{kWh} /$ year in total and are equivalent to $9.486 \times 10^{9}$ tons of standard coal while the geothermal resources of all major basins in China are $6.93 \times 10^{15} \mathrm{kwh}$, which is equivalent to $8.53 \times 10^{11}$ tons of standard coal. The total hot dry rock resources at depths 3.0-10.0 km reach $7.00 \times 10^{18} \mathrm{kWh}$, which is equivalent to $8.56 \times 10^{14}$ tons of standard coal, while the value in the United States is $4.64 \times 10^{18} \mathrm{kWh}$ (excluding Yellowstone National Park) [40]. Utilization of geothermal resources can be mainly divided into direct use and power generation in two ways. Direct use is mainly for heating, cooling, spa treatment, tourism, agriculture, greenhouse cultivation and so on. At present, the Yangbajing geothermal power plant using hot dry rock in Tibet is a model of geothermal power generation. In China, geothermal resources are geographically concentrated in Tianjin, Shaanxi, Hebei and other provinces or cities, while geothermal heat pumps are mainly located in Shenyang and Dalian City. Spa treatment and tourism are geographically concentrated in Beijing and southeast coast, while fish farming and agriculture are in Northern China [41].

\subsection{Geothermal Utilization of Geothermal Energy}

China, one of the earliest countries to make use of geothermal energy in the world, has a history of more than 2000 years of utilization of geothermal energy, especially hot springs. Direct use of geothermal energy in China has ranked first in the world for many years. According to the report of the World Geothermal Conference in 2010 and 2015 [42,43], geothermal direct use is shown in Table 4.

Table 4. Geothermal direct uses in 2009 and 2014 [42,43].

\begin{tabular}{ccccc}
\hline & \multicolumn{3}{c}{$\mathbf{2 0 0 9}$} & \multicolumn{2}{c}{$\mathbf{2 0 1 4}$} \\
\cline { 2 - 5 } Use & $\begin{array}{c}\text { Installed Capacity } \\
\text { (MWt) }\end{array}$ & $\begin{array}{c}\text { Annual Energy } \\
\text { Use (TJ/Year) }\end{array}$ & $\begin{array}{c}\text { Installed Capacity } \\
\text { (MWt) }\end{array}$ & $\begin{array}{c}\text { Annual Energy } \\
\text { Use (TJ/Year) }\end{array}$ \\
\hline Individual Space Heating & - & - & - & - \\
District Heating & 1291 & 14798 & 2946 & 33710 \\
Air Conditioning (Cooling) & - & - & - & - \\
Greenhouse Heating & 146 & 1688 & 154 & 1797 \\
Fish Farming & 197 & 2171 & 217 & - \\
Animal Farming & - & - & - & 1198 \\
Agricultral Drying & 82 & 1037 & 95 & 3304 \\
Industrial Process Heat & 145 & 2733 & 169 & - \\
Snow Melting & - & - & - & 31,637 \\
Bathing and Swimming & 1826 & 23886 & 2508 & - \\
Other Uses (Specify) & - & - & - & 74,041 \\
Subtotal & 3687 & 46,313 & 6089 & 100,311 \\
Geothermal Heat Pumps & 8898 & 75,348 & 11,781 & 174,352 \\
Total & 12,585 & 12,1661 & 17,870 & \\
\hline
\end{tabular}

The sum of geothermal heating area reached $6.03 \times 10^{7} \mathrm{~m}^{2}$ in 2014 ; the installed capacity reached $2946 \mathrm{MWt}$ with annual energy use of 33,710 TJ which was 1.3 times the value in 2009 (14,798 TJ). The total installed capacity of greenhouse heating in 2014 reached $154 \mathrm{MWt}$ with annual energy use of 1797 TJ which increased by 5.5\% in 2009. The total installed capacity of fish farming in 2014 reached $217 \mathrm{MWt}$, equivalent to annual energy use of $2395 \mathrm{TJ}$ which increased by $10.3 \%$ in 2009 . Geothermal energy was widely used in textile, wood, agriculture drying industries as well as in mineral water production [44]. In 2014, the total installed capacity of agricultural drying and industrial process heat reached 95 and $169 \mathrm{MWt}$, equivalent to annual energy utilization of 1198 and $3304 \mathrm{TJ}$, respectively. Hot springs were used for bathing, swimming and medical care and promoted the investors developing local tourism, so the hot spring industry was concentrated on tourism, real estate 
development. The total installed capacity of bathing and swimming reached $2508 \mathrm{MWt}$ with annual energy use of $31,637 \mathrm{TJ}$, which increased by $32.4 \%$ in 2009 . The total installed capacity of geothermal heat pumps reached $1178 \mathrm{MWt}$ with annual energy use of 100,311 TJ which increased by $33.1 \%$ in 2009 . In the development of geothermal, the growth of geothermal heating was the fastest, followed by the development of ground source heat pump.

\subsection{Geothermal Power Generation}

Geothermal power plants can be basically divided into two groups: steam cycles and binary cycles $[45,46]$. In the steam cycle the geothermal fluid is allowed to boil or "flash" above the boiling point by lowering the pressure. After becoming a two-phase fluid, the steam is separated from the brine and expanded in a turbine [47]. The process of lowering the pressure to boil the fluid is called the "flash process". The binary cycles use a secondary working fluid in a closed cycle. Heat exchangers are used to transfer heat from the geothermal fluid to the working fluid, the working fluid is vaporized and expanded in a turbine, and the cooled geothermal fluid is reinjected to the reservoir [10]. The first geothermal power generation station in China was established in December 1970 in Dengwu Village of Fengshun County, Guangdong Province, whereby China became the eighth country to use geothermal energy for power generation in the world. In 1971, China's first geothermal binary power station using $67^{\circ} \mathrm{C}$ geothermal water with a capacity of $50 \mathrm{kWe}$ was constructed in Wentang Village of Yichun County, Jiangxi Province. After that, five medium-low temperature geothermal power stations were built in Hunan, Guangxi, Shandong, Liaoning, and Heibei [48]. However, at the end of 1970s, only the power stations in Guangdong and Hunan were in operation [49]. China's geothermal power generation has some progress in recent years due to the application of the screw expander power unit. Jiangxi Huadian Electrical Power Co. Ltd. was dedicated in the development of the total flow system unit. It started a test of a 1 MWe unit in 2008 in Yangbajain, then completed the test and produced electric power in 2009, and added one more 1 MWe in 2010. It made Yangbajain geothermal power plant reach an installed capacity of 26.18 MWe and yielded $140 \mathrm{GWh} /$ year [43].

Geothermal projects are designed to be within time, budget, planned specification and legal and regulatory provisions while meeting the project objectives [50]. The cost of geothermal power development and production is affected by various kinds of parameters. Since power facilities have an expected lifetime, power costs of energy corresponds to the cost of power that amortizes all capital costs incurred over the expected life time of the power plant. The initial capital costs and financial interests are thus spread out over the total amount of energy produced throughout the entire production life of the power facility. The cost have two major components: (1) the initial capital investment and (2) operation and maintenance (O\&M) costs [51].

The initial investment cost involved in the development and construction projects, including surface survey, drilling evaluation, exploration, construction and a series of related costs while operation and maintenance (O\&M) costs are required by all plants to keep the power system in good working condition. Once the developer's rights on the resource are secured, geothermal power development typically begins with an exploration phase to define the geothermal resource. The confirmation phase which follows, seeks to confirm the power production potential of the resource as well as the economic feasibility of the project. Once both these phases are successful, the site development phase may begin. Major components of the site development phase are well drilling, steam gathering, and power plant construction. Most projects also require the construction of additional transmission infrastructure to be connected to the grid. Various kinds of permits (e.g., environmental, construction, etc.) are required for these phases and the process to obtain them may result in significant cost increases for the project.

The cost for different energy types are listed in Table 5 [52-54]. It calculates the levelized costs for new generation resources, plants entering service in 2022 while levelized cost of electricity (LCOE) was often cited as a convenient summary measure of the overall competiveness of different generating technologies which represented the per-kilowatthour cost (in real dollars) of building and operating 
a generating plant over an assumed financial life and duty cycle. Key inputs to calculating LCOE included capital costs, fuel costs, fixed and variable operations and maintenance (O\&M) costs, financing costs, and an assumed utilization rate for each plant type [53]. It consisted of $65.72 \%$ of the total system LCOE while fixed O\&M cost reached $30.97 \%$ in 2022. The cost of geothermal energy would represent the smallest cost of all estimated LCOE for new generation resources while the capacity factor would be the highest in 2022. In other words, geothermal generation power has a great future potential however the initial investment which was related to surface survey and drilling evaluation and to the need to cover the geological risk at the beginning of the exploration would need a large amount of capital investment. Meanwhile the construction of geothermal power stations takes 3 to 5 years while it would take more than 10 years from surface survey to power construction [52]. According to Barbier [55], geothermal prices were heavily increased by the long project development time, high cost and risk of exploratory drilling. Drilling can account for up to $50 \%$ of the total project cost [56]. According to the Japan Geothermal Association, the cost of $\mathrm{z}$ geothermal development with $50 \mathrm{MW}$ was estimated at approximately US $\$ 300$ million and its breakdown was US $\$ 100$ million for plant construction, US $\$ 150$ million for drilling of production and reinjection wells, US $\$ 20$ million for surface survey with exploratory drilling and resource evaluation, and others costs, including US\$30 million for environmental impact assessment while the breakdown of the estimated cost was not always applicable to every project, but considerable funds were required for drilling production and reinjection wells and plant construction [23]. High initial investment, long payback time and construction time are the main reasons that the geothermal industry is far behind other renewable energies. Therefore, for the initial investment subsidy in fiscal policies, a large amount of capital investment is required.

Table 5. Estimated LCOE for new generation resources, plants entering service in 2022 [52-54].

\begin{tabular}{|c|c|c|c|c|c|c|c|c|c|}
\hline \multirow{2}{*}{\multicolumn{2}{|c|}{ Type }} & \multicolumn{6}{|c|}{$\begin{array}{l}\text { U.S. Capacity-Weighted Average LCOE (2015 \$/MWh) } \\
\text { for Plants Entering Service in } 2022\end{array}$} & \multirow[b]{2}{*}{$\begin{array}{l}\text { Payback } \\
\text { (Years) }\end{array}$} & \multirow[b]{2}{*}{$\begin{array}{l}\text { Construction } \\
\text { (Years) }\end{array}$} \\
\hline & & $\begin{array}{l}\text { Capacity } \\
\text { Factor } \\
(\%)\end{array}$ & $\begin{array}{l}\text { Levelized } \\
\text { Capital } \\
\text { Cost }\end{array}$ & $\begin{array}{l}\text { Fixed } \\
\text { O\&M }\end{array}$ & $\begin{array}{c}\text { Variable O\&M } \\
\text { (including } \\
\text { Fuel) }\end{array}$ & $\begin{array}{l}\text { Transmission } \\
\text { Investment }\end{array}$ & $\begin{array}{c}\text { Total } \\
\text { System } \\
\text { LCOE }\end{array}$ & & \\
\hline & Wind & 42 & 43.3 & 12.5 & 0.0 & 2.7 & 58.5 & $0.4-1.4$ & $<1$ \\
\hline & Solar PV & 26 & 61.2 & 9.5 & 0.0 & 3.5 & 74.2 & $1-2.7$ & $0.3-0.5$ \\
\hline & Hydroelectric & 60 & 54.1 & 3.1 & 5.0 & 1.5 & 63.7 & $\begin{array}{c}0.5 \text { (large) } \\
11.8 \text { (small) }\end{array}$ & $\begin{array}{c}10-20 \\
1\end{array}$ \\
\hline & Ivanced Nuclear & 90 & 75 & 12.4 & 11.3 & 1.0 & 99.7 & - & - \\
\hline \multirow{2}{*}{$\begin{array}{l}\text { Natural } \\
\text { gas-fired }\end{array}$} & $\begin{array}{l}\text { Conventional } \\
\text { combined cycle }\end{array}$ & 87 & 12.8 & 1.4 & 41.2 & 1.0 & 56.4 & - & - \\
\hline & $\begin{array}{c}\text { Advanced } \\
\text { combustion turbine }\end{array}$ & 30 & 25.9 & 2.5 & 61.9 & 3.3 & 93.6 & - & - \\
\hline
\end{tabular}

\section{Research Methods}

\subsection{Characteristics of the Effects of Fiscal and Taxation on Geothermal Industry}

Fiscal and taxation policies are regulations that act as a means of economic operation. The government uses them to adjust the demand and supply of the geothermal industry. For promoting the development of the geothermal industry, the government directly gives subsidies, government procurement and transfer payments to the geothermal industry. Meanwhile, it can also give more preferential tax relief ways. Among the development stages of the geothermal industry, it is necessary that the government input the direct subsides as the incentives before the geothermal industry comes into the commercial stage. Subsidies would be the main driving force for geothermal development. When the geothermal industry comes to the stage of commercial operation, the government should 
use taxation policies to adjust its development. If a certain degree of incentives should be maintained for the geothermal industry, it should concentrate on the market mechanism. The major fiscal and taxation policies are shown in Table 6 . This paper classifies the process of geothermal industry into five stages: surface survey and evaluation, research and development, utilization and O\&M, beginning of commercialization and commercialization. Meanwhile, on the subsidies side one might include not only direct government transfers and tax breaks, which are primarily emphasized already, but also the monetized value of mandates to use minimum amounts of specific energy sources and other special privileges that might be granted to utility companies to use one type of resource relative to another [51]. The purpose of subsidy programs is to cause supply or demand for the geothermal energy sources to be greater than they would be in a free market. Overall, in the geothermal industry, subsidies should be focused on the life cycle of geothermal industry from surface survey to utilization and should be given to the producers and consumers. The initial investment is very vital for geothermal development and the amount of subsidies should be more than in other stages. In the pre-commercialization phase, the government should give free tax policies to promote the geothermal industry. When the geothermal industry is in the commercial stage, the market of geothermal heating and electricity is mature and the investors can obtain their profits, the government may levy fees to make up for the input of subsidies in the initial phase.

Table 6. Different stages of geothermal industry for fiscal and taxation policies.

\begin{tabular}{|c|c|c|c|c|c|}
\hline Stages & $\begin{array}{l}\text { Surface Survey } \\
\text { and Evaluation }\end{array}$ & $\begin{array}{l}\text { Research and } \\
\text { Development }\end{array}$ & $\begin{array}{l}\text { Utilization } \\
\text { and } O \& M\end{array}$ & $\begin{array}{c}\text { Beginning of } \\
\text { Commercialization }\end{array}$ & $\begin{array}{c}\text { Commercialization } \\
\text { (Market) }\end{array}$ \\
\hline Fiscal policies & Main & Main & Main & Supplement & Supplement \\
\hline Tax policies & Free & Free & Tax preference & Supplement & Normal \\
\hline Risk & The higher & high & Medium & low & The lower \\
\hline
\end{tabular}

\subsection{Systematic Dynamic Model}

The system dynamics methodology was developed to analyze complex systems and improve decision-making and policy formation. The methodology identifies the system under consideration and its boundaries, and uses mathematical equations to represent relationships and feedback loops among key elements of the system [57]. This enables the generation and analysis of a range of scenarios [58,59]. SD is applied in business planning, public policy management, energy and environment policy, and dynamic decision making. SD is the use of informal maps and formal models with the aid of computer simulation to uncover and understand endogenous sources of system behaviour. Simulation modelling is an essential aspect of SD [60,61]. Generally, SD can be defined as "a theory of system structure and a set of tools for representing complex systems and analyzing their dynamic behaviour" [62,63]. The modelling procedure in SD comprises: definition of problem, hypothesis formulation, developing simulation model, model testing and policy design and assessment. The structure of the system is represented by interrelationships among the parameters and processes and feedback loops in the model structure [64]. By modelling these feedback loops, one gains insight into the dynamic complexity of actions, as well as their short and long-run effects. Another advantage of SD is that it is not limited to the numerical data sources; rather it draws from different sources of information and data types, and can be applied to varied fields and disciplines.

System Dynamics tools and techniques include two categories: Causal Loop Diagrams and System Dynamics Computer Models [65]. They can be used to handle the most complex system complexities, thereby very valuable information can be obtained [66]. China's geothermal industry is just in the early stages of development, and data from the geothermal industry is not available. Therefore, this paper adopts the Causal Loop Diagrams to analyze the fiscal and tax policies of the geothermal industry. Causal Loop Diagrams are an important tool for illustrating the structure of the system feedback, which consists of a positive feedback loop and a negative feedback loop. The feedback loop is connected in a causal chain which has algebraic polarity. Table 7 shows the polarity of the causal chain. One is a 
positive (+) causal chain. The greater the dependent variable is, the greater the variable results come up. The other is a negative (-) causal chain. The greater the dependent variable is, the smaller the variable is [67].

Table 7. Polarity of the causal chain.

Explanation
If $\mathrm{X}$ increase (decrease), $\mathrm{Y}$ increase (decrease) above (below) the amount of the original data.

The SD approach has been considered in the sustainable management of energy systems, while it has not been addressed in the development of the geothermal industry. Scholars use SD methodology to simulate the process of energy efficiency improvement [23-26] and the behavior of the clean energy sectors $[68,69]$. SD models are widely built to explore the effects of energy consumption and emission reduction policies [70-75]. Some scholars have applied system dynamics models to simulate the development of nuclear power [76], photovoltaic power [77], unconventional oil [78], electricity industry [79] to simulate the developing trends and explore the support policies. The reasons to choose systematic dynamic model in this paper can be summarized as follows:

(1) The mechanism of fiscal and taxation is a complex system which includes different kinds of variables such as subsidies for surface surveys, drilling evaluation, exploration, utilization, O\&M and taxes including circulation tax, resources tax, income tax, etc. Different kinds of variables influence the development of the geothermal industry in various nonlinear relations and interconnect with each other.

(2) The mechanism is also a long term system and has a long term cause-and-effect relationship. If the activities of surface survey slows, the utilization of geothermal energy will have a feedback effects.

In all, there was no systematic analysis of geothermal industry and this paper established a SD model to simulate the development of geothermal industry. The fiscal and taxation of geothermal industry will influence the development system of geothermal energy from five respects:

(1) Increase the fiscal support from surface survey of geothermal resources to start the geothermal industry;

(2) Approve the subsidy for surface survey, drilling evaluation, exploration and utilization to cut the costs of the geothermal industry, and a long term subsidy to stimulate the geothermal industry;

(3) Lower the circulation tax, resources tax, corporate income tax and other taxes and increase the carbon tax, to encourage technical research to promote the development of the geothermal industry;

(4) Provide carbon taxes to restrict the use of the traditional resources;

(5) Lower the costs of the geothermal industry to increase the profit to affect the demand for geothermal energy.

\section{Results}

\subsection{Fiscal Policies Affecting on Geothermal Industry}

The risk of investigation of geothermal resources is relatively bigger, so the requirement of technology and exploration costs are higher. Provided with the support and help from the government, the enterprises would be willing to explore and invest in the geothermal energy. Surface exploration and drilling evaluation are essential tasks for the geothermal industry and account for the main initial investment. If the country or enterprises cannot evaluate the geothermal energy and uncertainty of geothermal industry rises, no one would like to develop the geothermal industry [80]. 
The government uses investments and subsidies to increase the investment in geothermal industry. Table 8 shows the total investments in geothermal industry in China. It illustrates that the funds are increasing from $2.1 \%$ of the total investment in 2002-2004 to $8.7 \%$ in 2010-2014. The intial investments in the geothermal industry mainly focused on field development, including production drilling and surface equipment, which reached US $\$ 424.7$ million. From 2010 to 2014, a total of US\$97 million has supported the projects of survey and assessment of geothermal resources in China from the Ministry of Land and Resources. It would find shallow geothermal energy and conventional geothermal energy resources and it included a preliminary study for hot dry rock resources [44]. However, the total investments in the geothermal industry from the public funds are smaller than those from private enterprises.

Table 8. Total investments in the geothermal industry [52].

\begin{tabular}{|c|c|c|c|c|c|c|}
\hline \multirow{3}{*}{ Period } & \multirow{2}{*}{$\begin{array}{c}\text { Research and Development; } \\
\text { Surface Exploration and } \\
\text { Drilling }\end{array}$} & \multirow{2}{*}{$\begin{array}{c}\text { Field Development Including } \\
\text { Production Drilling and } \\
\text { Surface Equipment }\end{array}$} & \multirow{2}{*}{$\begin{array}{l}\text { Direct } \\
\text { Use }\end{array}$} & \multirow{2}{*}{$\begin{array}{l}\text { Electrical } \\
\text { Use }\end{array}$} & \multicolumn{2}{|c|}{ Funding Type } \\
\hline & & & & & Private & Public \\
\hline & $10^{6}$ USD & $10^{6}$ USD & $10^{6}$ USD & $10^{6}$ USD & $\%$ & $\%$ \\
\hline 2000-2004 & 5.4 & 80.9 & 172.8 & - & 97.9 & 2.1 \\
\hline 2005-2009 & 8.2 & 207.8 & 1142.9 & 2.2 & 97.7 & 2.3 \\
\hline 2010-2014 & 28.5 & 424.7 & 1485.8 & 54.8 & 91.3 & 8.7 \\
\hline
\end{tabular}

For the investments in research and development, key technology research for geothermal development has focused on prospective hot dry rock projects as key points. Jilin University combined with other universities and research institutes received grants for the research named "Key Technology Research on Development and Integrated Utilization of Hot Dry Rock Heat Energy" from the Ministry of Science and Technology (MOST) as "863 Project". Another HDR research topic from Ministry of Land and Resources (MLR) would carry out test drilling in Tibet and Yunnan or in the southeast coastal region. Another MOST funded "863 Project" named "Key Technology Research and Demonstration of Medium-Low Temperature Geothermal Power Generation" was carried out to promote the geothermal power generation technology. Its target was a $500 \mathrm{kWe}$ prototype of binary circle power generator with thermal efficiency higher than 6\% [39]. Strengthening support for the innovation of geothermal development technology is essential and the key to the development of geothermal industry lies in the development of core technology. Technological innovation is an important driving force to reduce the cost of geothermal energy. However, our country has a small part of geothermal innovative technologies and it is necessary to set up more special fund to support development of geothermal technology innovation.

For the geothermal electrical use, the government instituted a feed-in tariff that paid businesses and homeowners a premium price for the geothermal electricity in Tibet. The cost of geothermal electricity was $0.7 \mathrm{RMB} / \mathrm{kWh}$. The government gave the subsidy of $0.65 \mathrm{RMB} / \mathrm{kWh}$ to the geothermal electricity businesses. In fact, the feed-in tariff of geothermal electricity was $0.9 \mathrm{RMB} / \mathrm{kWh}$ which was higher than the $0.5 \mathrm{RMB} / \mathrm{kWh}$ of the wind electricity, and lower than PV electricity which was $1 \mathrm{RMB} / \mathrm{kWh}$. It estimated that Longyuan Yangbajing geothermal power station in Tibet could get begin to get investment returns within 8-10 years and then it could come to the commercial stage and be profitable. Subsidies to producers and consumers are an effective way to encourage enterprises to develop the industry and incentivize consumers to utilize the geothermal energy.

Figure 2 is a circuit diagram of the causal impact of fiscal and tax policies on the geothermal industry. With the growth of exploration investment, the number of proven reserves of geothermal resources and recoverable reserves will increase, so that the willingness of enterprises to explore and develop geothermal industry may be enhanced. The increase of the exploitation will affect the utilization of geothermal resources. The numerous geothermal resources lead to the decreasing price of geothermal heating and geothermal electricity. As a result, it can decrease the expected price and encourage consumers to use geothermal heating rather than coal or gas. When the enterprises can 
obtain profits, they should compensate the government and pay a certain tax. If the expected price of geothermal heating or electricity is not high, the government and the enterprises will develop geothermal industry or scientific geothermal energy research.

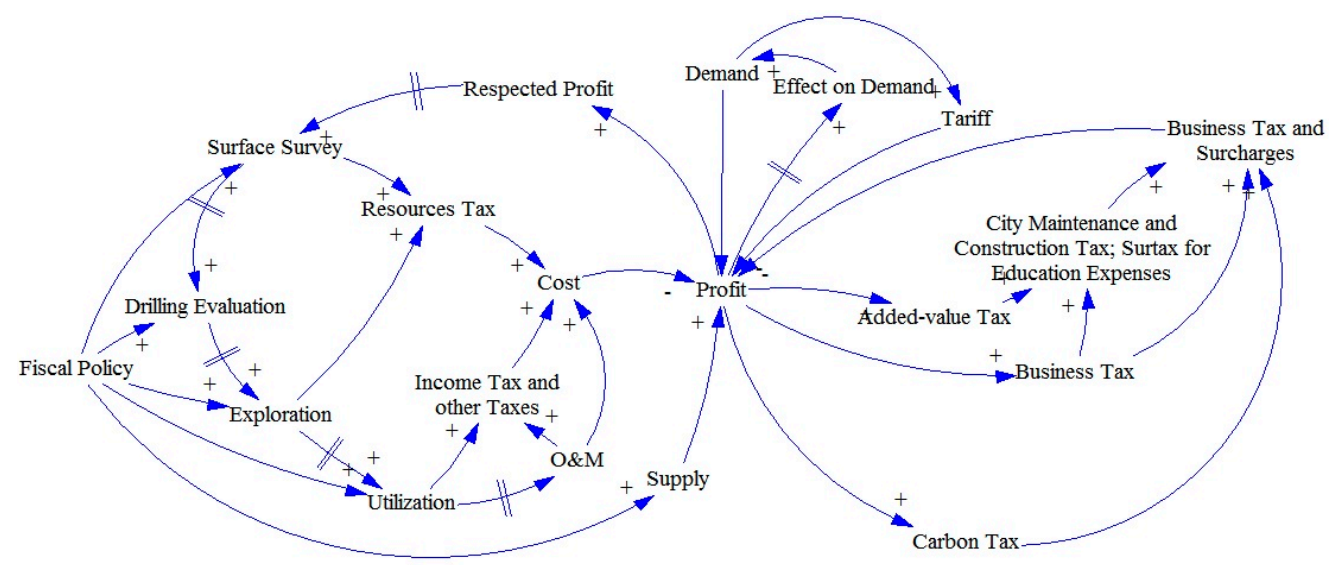

Figure 2. System of fiscal and tax policies affecting geothermal industry.

\subsection{Tax Policies on Geothermal Industry}

\subsubsection{Circulation Tax}

Circulation tax (CT) in geothermal industry includes value-added tax (VAT), business tax (BT), urban maintenance and construction tax (UMCT) and education surcharge (ES). VAT is the main tax in $\mathrm{CT}$ on the production and circulation in geothermal industry. VAT is a tax levied on the production of geothermal energy. Considering that there is little deductible input tax, the normal VAT, which is up to $17 \%$, is not reasonable, and that increases the cost of geothermal development and utilization of the project. State and local governments have not yet developed a unified VAT rate for the geothermal industry, but the preferential policies on the part of the new energy industry have been given. The wind power industry is subjected to a $8.5 \%$ tax; the rate of artificial methane and biomass is $13 \%$; small hydro is $6 \%$. Currently geothermal industry is in the early stage of development. VAT can not only reduce the burden of running the project, but also reflect fairness for new energy development. The tax rate in the geothermal industry should be $6 \%$ according to the minimum rate. Lower VAT can decrease the orgaic capital investment, reduce the industry burden significantly, and enhance technological innovation incentives. BT in geothermal is a tax payable against turnover by all enterprises and individuals undertaking the following business activities: providing taxable services, including communication, transport, heating or electricity power construction, finance and insurance, and service industries; transferring the provision of intangible assets; and selling immovable properties. BT is paid based on CT. The geothermal industry is more complex, an distributed in various industries. It may be levied in accordance with the minimum rate of $3 \%$.

Urban maintenance and construction tax (UMCT) and education surcharges (ES) in the geothermal industry are levied on the basis of valued add tax and business tax. VAT in the geothermal industry is equal to the output VAT reduced by income tax. VAT is levied by enterprises rather than consumers, so that VAT increases the burden of consumers. If the UMCT and ES were to increase, the costs of geothermal heating and thermal electricity would rise. VAT has an effect on the amount of consumption. The rising price of geothermal heating and electricity causes CT to soar and that will increase the cost of geothermal exploration. The rising cost leads to the increasing price of geothermal heating and electricity. In that way, the tax increases the price strongly. CT increases the cost of geothermal exploitation and decreases the profits of enterprises. Therefore, it will affect the incentives of geothermal exploration and utilization in the geothermal industry. 


\subsubsection{Resources Tax}

Resources Tax (RT) in the geothermal industry is a tax on profits generated from the drilling exploration of geothermal resources and it adjusts the interests of the relationship between the various economic agents of a fiscal and taxation system. RT mainly consists of royalties, compensation fees for resource depletion, ecological compensation fees and so on. The role of RT is similar to the compensation fee for resources depletion levied before. In China, the enterprises should pay the resources tax and compensation fee for resources depletion in the same time. Currently departments from different administrations levy the taxes, which results in chaos and increases the burden of the enterprises [81]. Regarding the high cost and long-term period of geothermal exploration, RT should be free or low rate to reduce the costs of the geothermal industry and promote its development. When the industry comes into the commercialization stage, the tax rate could return to $5 \%$, the normal tax of the renewable energy development.

\subsubsection{Carbon Tax}

Carbon tax is a tax levied on the carbon content of fuels. It offers a potentially cost-effective method to reduce greenhouse gas emissions. The attraction of a carbon tax in China would not rest mainly on its contribution to avoiding climate change, but rather its contribution to reducing air pollution, which derives heavily from the use of coal and, increasingly, from automotive emissions in the larger cities. Therefore, the enterprises will transfer their investment into the renewable energy industry, especially to the geothermal industry. In the geothermal industry, there are the least carbon emissions compared with other resources. China's policy on reducing carbon emissions has attracted worldwide attention. The need to reduce carbon emissions would promote a huge investment in the future to solve the problem for a long period of time. It is recommended to establish a first pilot of a small carbon tax on the basis of the current situation. According to the current domestic electricity prices to ease the pressure, the levied carbon taxis recommended as 10 yuan/tonne [82].

\subsubsection{Corporate Income Tax and Other Taxes}

State Administration of Taxation issued the regulation "Enterprise Income Tax Law" and implemented regulations issued on the "State Administration of Taxation on the implementation of high-tech enterprise income tax issues related to notice". It implements income tax relief for high-tech enterprises. The main regulations include: high-tech enterprises' tax rate was reduced to $15 \%$; the expenses incurred in developing new products, new technologies and new techniques shall be deducted before calculation of enterprises' income tax in accordance with taxation laws. From the profit-making year, the enterprise income tax will be exemptible for the first three years and at half rate reduction for the subsequent three years. Corporate income tax (CIT) in the geothermal industry are levied at a $15 \%$ rate after the first three-years of free tax and the next three year at a half rate reduction. It is not the levied directly on the price, but it will affect the cost of geothermal exploration. When CIT in geothermal industry decreases, the profits from geothermal industry would be lower, so that the price of geothermal heating and thermal electricity may move up in the indirect way.

There are tariffs, land use taxes, environmental monitoring costs, environmental management compensation, pollutant discharge fees, customs duties, import and export value-added taxes, and farmland occupation tax in the geothermal industry. A tariff is a tax on imports or exports. These taxes will increase the cost of exploration, thereby stimulating costs. China began to encourage the development of national projects with tax-exempted imported equipment, and the tax on imported equipment has been free since 1998. The imported equipment from China's foreign investment in renewable energy projects and domestic investment in renewable energy project for self-use has been exempt from tax since 2004. Therefore, other taxes are exempt for the implementation of the geothermal industry. 


\subsubsection{Profits Affecting on Geothermal Industry}

The geothermal industry consists of five important components: surface survey, drilling evaluation, exploration and development (geothermal engineering design and construction), utilization (heating and electrical use) and O\&M. There are delays in the industrial cycle, because starting new exploration activities may take several years to find new reserves of geothermal resources. Before the utilization, the infrastructure may need time for construction. Government encourages enterprises to do new exploration of geothermal energy and the enterprises can benefit from the return on the use of resources and income subsidies. If the expected return is attractive, exploration companies will develop geothermal energy and production. If companies were to believe that the expected return is low, they would not be willing to begin a new exploration and exploitation of geothermal energy. Exploration and development activities are relatively independent of capital investment decisions on the basis of which companies may decide to start exploration and development, and then expect to decide whether to grant development and production. There is an inherent uncertainty from exploration to actual development, which makes investment in exploration and development a very difficult and extremely complex process. Therefore, stability and predictability of the supply of geothermal resources has an extremely important role.

\subsubsection{Taxation in the Geothermal Industry}

Table 9 shows the results of taxes at the different stages of the geothermal industry. Geothermal enterprises pay various taxes which increase the cost of geothermal exploration and taxes increase the price of geothermal heating and thermal electricity.

Table 9. Comparison of taxes in the geothermal industry.

\begin{tabular}{|c|c|c|c|c|}
\hline Tax & Content & Before & After & Merchandised \\
\hline Resources Tax (RT) & $\begin{array}{l}\text { Tax on profits generated from the } \\
\text { drilling exploration of geothermal } \\
\text { resources and it adjusts the interests of } \\
\text { the relationship between the various } \\
\text { economic agents of a fiscal and } \\
\text { taxation system }\end{array}$ & $\begin{array}{l}\text { Exploration fee: } 100 \mathrm{RMB} / \mathrm{km}^{2} \cdot \text { year } \\
\text { from } 1-3 \text { years and an increase of } \\
100 \mathrm{RMB} / \mathrm{km}^{2} \cdot \text { year from the } 4 \text { th year; } \\
\text { the highest fee is no more than } \\
500 \mathrm{RMB} / \mathrm{km}^{2} \cdot \text { year; } \\
\text { Mining royalties: } \\
1000 \mathrm{RMB} / \mathrm{km}^{2} \cdot \text { year; Resources } \\
\text { ecological compensation fee: mineral } \\
\text { sales revenue } \times \text { compensation rate } \\
(2 \%-4 \%) \times \text { Ratio of Mining Recovery }\end{array}$ & Free & $5 \%$ \\
\hline Corporate Income Tax (CIT) & $\begin{array}{l}\text { Tax imposed on individuals or entities } \\
\text { that varies with the income or profits }\end{array}$ & $25 \%$ & $15 \%$ & $17 \%$ \\
\hline Value-Added Tax (VAT) & $\begin{array}{l}\text { Tax levied on the production of } \\
\text { geothermal energy }\end{array}$ & $17 \%$ & $6 \%$ & $13 \%$ \\
\hline Business Tax (BT) & $\begin{array}{l}\text { Tax payable against turnover by all } \\
\text { enterprises and individuals } \\
\text { undertaking the following business } \\
\text { activities: providing taxable services, } \\
\text { including communication, transport, } \\
\text { heating or electricity power } \\
\text { construction, finance and insurance, } \\
\text { and service industries; transferring the } \\
\text { provision of intangible assets; and } \\
\text { selling immovable properties }\end{array}$ & $6 \%$ & Free & $6 \%$ \\
\hline Tariff & Tax on imports or exports & $3 \%$ & Free & $3 \%$ \\
\hline $\begin{array}{c}\text { Urban Maintenance and } \\
\text { Construction Tax (UMCT) } \\
\text { and EDUCATION } \\
\text { Surcharge (ES) }\end{array}$ & $\begin{array}{l}\text { Taxes based on value add tax, business } \\
\text { tax and consumer tax }\end{array}$ & $\begin{array}{c}\mathrm{UMCT}=(\mathrm{VAT}+\mathrm{BT}) \times 7 \% \\
\mathrm{ES}=(\mathrm{VAT}+\mathrm{BT}) \times 3 \%\end{array}$ & Free & Free \\
\hline Carbon Tax & Tax levied on the carbon content of fuels & - & Free & $10 \mathrm{RMB} /$ ton \\
\hline
\end{tabular}

Changes in corporate profits will affect the exploration, development and utilization of geothermal industry as well as other activities. While the CT, RT are levied in accordance with a certain percentage of the price, these taxes will result in rising prices which directly increase the cost of geothermal 
enterprises. Corporate income tax (CIT), land use tax, carbon tax, farmland occupation tax and other taxes will also increase the cost when the geothermal industry comes reaches the commercialization stage. Whether this part of the cost can be passed on to the price of geothermal heating and geothermal electricity directly, affects the exploration, development and utilization of the geothermal industry. The price of geothermal heating and geothermal electricity is subject to strict government control. If the price are lower than the market equilibrium price after government subsidies, this could promote the development of the geothermal industry to reduce costs and improve the development and utilization of geothermal initiatives. Considering the of fiscal and tax mechanism system, the government should lower the various taxes in the geothermal industry to promote the healthy development of geothermal energy for our national energy security.

\section{Conclusions}

The geothermal industry has great potential for future world energy supply. The business knowledge in the field is increasing fast and the number of enterprises in the geothermal industry is growing. China's geothermal energy potential is tremendous and the Chinese government considers energy conservation and emission reduction as a national development strategy. China has positive policies with geothermal subsidies to promote the geothermal industry, but it has no systematic mechanism of fiscal and tax policies. This paper made the efforts to highlight the contribution of systematic dynamics for fiscal and tax policies in the geothermal industry.

(1) Promoting the geothermal industry is a complex system involving exploration, evaluation, development and utilization. In China, every stage of the geothermal industry should be focused on. Even though China's recent policies actions have broken the high-cost limitation and stimulated investment in the geothermal industry, utilization of geothermal heating and geothermal electricity are undoubtedly facing enormous development opportunities.

(2) From the results of a systematic study of the fiscal and tax dynamics in the geothermal energy sector, fiscal and taxation policies interact with each other in the development of the geothermal industry. Regarding China is in the pre-commercialization stage, the various subsidies should be put into the geothermal industry such as surface survey, drilling evaluation, exploration, utilization and O\&M. The government should increase the the initial investment of survey and drilling to the manufacturers which plays an important role to start the geothermal industry and strengthen support for the innovation of geothermal technologies and grant feed-in tariffs to consumers. These provide fiscal support to convert small electricity consumers to producers. Before the geothermal industry comes to the commercialization stage, China should give various and long term subsidies and levy less tax while it should levy the tax when the market of the geothermal industry becomes mature.

(3) Geothermal enterprises pay various taxes in the different stages of the geothermal industry. The government should use taxation policies as a leverage to enhance the development of the geothermal industry before and after commercialization.

Acknowledgments: The authors gratefully acknowledge the support provided by the National Natural Science Foundation of China under Grant No. 71173200, the Development and Research Center of China Geological Survey under Grant No. 12120114056601 and National Science and Technology Major Project under Grant No. 2016ZX05016005-003.

Author Contributions: Yong Jiang and Yalin Lei designed the research; Yong Jiang and Li Li collected and compiled all the data and literature; Yong Jiang, Li Li. and Jianping Ge finished the experiment and calculation; Yalin Lei and Jianping Ge analyzed the results and put forward the policies; Yong Jiang. and Yalin Lei revised the manuscripts and approved the manuscripts; Yalin Lei is responsible for the future questions from readers as the corresponding author. All authors read and approved the final manuscript.

Conflicts of Interest: The authors declare no conflict of interest. 


\section{References}

1. Kana, J.D.; Djongyang, N.; Raïdandi, D.; Nouck, P.N.; Dadjéa, A. A review of geophysical methods for geothermal exploration. Renew. Sustain. Energy Rev. 2015, 44, 87-95. [CrossRef]

2. Malafeh, S.; Sharp, B. Role of royalties in sustainable geothermal energy development. Energy Policy 2015, 85, 235-242. [CrossRef]

3. Han, Z.-S.; Zhen, K.-Y.; Bin, D.-Z. Working Group on Middle to Long Term Development Strategy of Energy in China. In The Mid and Long-Term $(2030,2050)$ Development Strategy of Energy in China; Renewable Energy; Science Press: Beijing, China, 2011.

4. Jin, H.; Lior, N.; Zhang, X. Energy and its sustainable development for China: Editorial introduction and commentary for the special issue of energy-The international journal. Energy 2010, 35, 4246-4256. [CrossRef]

5. Ma, L.; Allwood, J.-M.; Cullen, J.-M.; Li, Z. The use of energy in China: Tracing the flow of energy from primary source to demand drivers. Energy 2012, 40, 174-188. [CrossRef]

6. Gallup, D.L. Production engineering in geothermal technology: A review. Geothermics 2009, 38, 326-334. [CrossRef]

7. Kana, J.D.; Djongyang, N.; Raïdandi, D.; Nouckd, P.N.; Nouayoud, R.; Tabode, T.C.; Sandaf, O. Geophysical investigation of low enthalpy geothermal potential and ground water reservoirs in the Sudano-Sahelian region of Cameroon. J. Afr. Earth Sci. 2015, 110, 81-91. [CrossRef]

8. Trumpy, E.; Donato, A.; Gianelli, G.; Gola, G.; Minissale, A.; Montanari, D.; Santilano, A.; Manzella, A. Data integration and favourability maps for exploring geothermal systems in Sicily, southern Italy. Geothermics 2015, 56, 1-16. [CrossRef]

9. Van der Meer, F.; Hecker, C.; Ruitenbeek, F.V.; van der Werff, H.; de Wijkersloothb, C.; Wechslerb, C. Geologic remote sensing for geothermal exploration: A review. Int. J. Appl. Earth Observ. Geoinform. 2014, 33, 255-269. [CrossRef]

10. Geirdal, C.A.C.; Gudjonsdottir, M.S.; Jensson, P. Economic comparison of a well-head geothermal power plant and a traditional one. Geothermics 2016, 53, 1-13. [CrossRef]

11. Liu, F.-G.; Hu, -D.; Wu, M.; Lu, Y. Economic analysis on investment in geothermal power generation. Sin-Glob. Energy 2014, 19, 24-30.

12. Ibrahim, R.; Fauzi, A.; Suryadarma. The progress of geothermal energy resources activities in Indonesia. In Proceedings of the World Geothermal Congress 2005, Antalya, Turkey, 24-29 April 2005.

13. Zarrouk, S.J.; Moon, H. Efficiency of geothermal power plants: A worldwide review. Geothermics 2014, 51, 142-153. [CrossRef]

14. Hähnlein, S.; Bayer, B.; Ferguson, G.; Blum, P. Sustainability and policy for the thermal use of shallow geothermal energy. Energy Policy 2013, 59, 914-925. [CrossRef]

15. Martín-Gamboa, M.; Iribarren, D.; Dufour, J. On the environmental suitability of high- and low-enthalpy geothermal systems. Geothermics 2015, 53, 27-37. [CrossRef]

16. Shortall, R.; Davidsdottir, B.; Axelsson, G. Geothermal energy for sustainable development: A review of sustainability impacts and assessment frameworks. Renew. Sustain. Energy Rev. 2015, 44, 391-406. [CrossRef]

17. Guan, X. Adopting the experiences to promote geothermal industry. Hydrogeol. Eng. Geol. 2011, 38, 1-5.

18. Daysh, S.; Chrisp, M. Environmental planning and consenting for Wairakei: 1953-2008. Geothermics 2009, 38, 192-199. [CrossRef]

19. Zhou, G.-H.; Huang, R.; Xie, P.-P. Component analysis of geothermal industry. Sci. Technol. Manag. Land Resour. 2014, 20, 47-53.

20. Guo, L.-H. Study on the Industry Investment Fund under the Exploitation of Geothermal Resources. Ph.D. Thesis, Gilin University, Changchun, China, 2009.

21. Van Bart Campen, B.; Petursdottir, H. Geothermal sustainability regulation in Iceland and New Zealand. In Proceedings of the European Geothermal Congress 2016, Strasbourg, France, 19-24 September 2016.

22. Kaneko, M.; Kaneko, M.M.; Akakura, K.; Yamamur, S.; Inoue, Y. A proposal of fiscal incentives to accelerate geothermal development in Indonesia. J. Geotherm. Res. Soc. 2010, 32, 97-108.

23. Hayashi, M.; Kuge, K.; Sato, H.; Tanaka, H. Cooperation in geothermal development at Great Rift Valley in Africa. In Proceedings of the World Geothermal Congress 2015, Melbourne, Australia, 19-25 April 2015. 
24. Lund, J.W.; Bloomquist, R.D. Development of geothermal policy in the United States. In Proceedings of the Thirty-Seventh Workshop on Geothermal Reservoir Engineering, Stanford, CA, USA, 30 January-1 February 2012.

25. Campen, B.V.; Rai, K. Geothermal Policy and Regulation-Cases from Chile, Kenya, New Zealand and the Philippines; Technical Report; University of Auckland Geothermal Institute; International Renewable Energy Agency (IRENA): Auckland, New Zealand; August 2015.

26. Ulgado, A.F.; Butiu, E.D. Policy reforms in geothermal energy resource development and utilization in the Philippines. GRC Trans. 2006, 30, 1097-1100.

27. Budd, A.R.; Gerner, E.J. Externalities are the dominant cause of faltering in Australian geothermal energy development. In Proceedings of the World Geothermal Congress 2015, Melbourne, Australia, 19-25 April 2015.

28. Imolauer, K.; Ueltzen, M. Risk mitigation systems in Comparison. In Proceedings of the World Geothermal Congress 2015, Melbourne, Australia, 19-25 April 2015.

29. Dumas, P.; Angelino, L. Financing geothermal energy. In Proceedings of the World Geothermal Congress 2015, Melbourne, Australia, 19-25 April 2015.

30. Bommensatt, N.; Maestro, A.C.; Laplaige, P. French financial incentives to promote geothermal heat. In Proceedings of the World Geothermal Congress 2015, Melbourne, Australia, 19-25 April 2015.

31. Hidefumi, N.; Sukenori, H.; Toshiyuki, T.; Tadaaki, S. On the Japan's geothermal energy development and the role of JOGMEC. In Proceedings of the World Geothermal Congress 2015, Melbourne, Australia, 19-25 April 2015.

32. Zhao, X.-G.; Wan, G. Current situation and prospect of China's geothermal resources. Renew. Sustain. Energy Rev. 2014, 32, 651-661. [CrossRef]

33. Miao, S. Foreign geothermal policies affecting on China. J. Chifeng Univ. 2015, 31, 87-90.

34. Zeng, B.Y. Recommendations on improving fiscal and taxation policies of shale gas industry in China. Open J. Soc. Sci. 2016, 4, 48-54. [CrossRef]

35. Gao, L.Z. The long-term relationships among China's energy consumption sources and adjustments to its renewable energy policy. Energy Policy 2012, 47, 456-467.

36. BP Statistical Review of World Energy 2016 Workbook 2016. Available online: http://www.bp.com/ (accessed on 20 August 2016).

37. Evans, A.; Strezov, V.; Evans, T.J. Assessment of sustainability indicators for renewable energy technologies. Renew. Sustain. Energy Rev. 2009, 13, 1082-1088. [CrossRef]

38. Jiang, J. China's Energy Policy 2012; Information Office of the State Council: Beijing, China, 2012.

39. Long, H.; Zhu, Q.; Tian, P.; Hu, W. Technologies and applications of geophysical exploration in deep geothermal resources in China. In Proceedings of the World Geothermal Congress 2015, Melbourne, Australia, 19-25 April 2015.

40. Tester, J.W. The Future of Geothermal Energy: Impact of Enhanced Geothermal Systems (EGS) on the United States in the 21st Century; Massachusetts Institute of Technology: Cambridge, MA, USA, 2006.

41. Zhou, Z.-Y.; Liu, S.-L.; Liu, J.-X. Study on the characteristics and development strategies of geothermal resources in China. J. Nat. Resour. 2015, 30, 1210-1221.

42. Zhang, J.-H.; Wei, W. Discussion on distribution characteristics and utilization of geothermal resources in China. Nat. Resour. Econ. China 2011, 8, 23-28.

43. Zheng, K.-Y. Speeding up industrialized development of geothermal resources in China-Country update report 2010-2014. In Proceedings of the World Geothermal Congress 2015, Melbourne, Australia, 19-25 April 2015.

44. Zhu, J.-L.; Ku, K.-Y.; Lu, X.-L.; Huang, X.; Liu, K.; Wu, X. A review of geothermal energy resources, development, and applications in China: Current status and prospects. Energy 2015, 93, 466-483. [CrossRef]

45. Zhou, D.-J. The overview of geothermal power generation. Electr. Power Surv. Des. 2003, 3, 1-6.

46. Xu, Y.-B.; Wang, M.; Pan, J.; Li, B. Characteristics of geothermal resource-based power generation technology and development trends. Sino-Glob. Energy 2012, 17, 29-34.

47. Zheng, K.-Y.; Pan, X.-P. Status and prospect of geothermal generation development in China. Sino-Glob. Energy 2009, 14, 45-48.

48. Zheng, K.; Mo, Y.; Chen, L. Twenty years of geothermal heat pumps in China. In Proceedings of the World Geothermal Congress 2015, Melbourne, Australia, 19-25 April 2015. 
49. Zheng, K.; Dong, Y. The possible role of geothermal energy to the Chinese energy development. In Proceedings of the 8th Asian Geothermal Symposium, Hanoi City, Vietnam, 9-12 December 2008.

50. Ngugi, P.K. Risks and risk mitigation in geothermal development. In Proceedings of theUtilization of Low- and Medium-Enthalpy Geothermal Resources and Financial Aspects of Utilization, Santa Tecla, El Salvador, 23-29 March 2014.

51. Hance, C.N.; Gawell, K. Factors affecting cost of geothermal power development and production. GRC Trans. 2005, 29, 449-454.

52. Li, K.-W.; Bian, H.-Y.; Liu, C.-W.; Zhang, D.; Yang, Y. Comparison of geothermal with solar and wind power generation systems. Renew. Sustain. Energy Rev. 2015, 42, 1464-1474. [CrossRef]

53. Annual Energy Outlook 2016; U.S. Energy Information Administration: Washington, DC, USA, 2016.

54. Kenny, R.; Law, C.; Pearce, J.M. Towards real energy economics: Energy policy driven by life-cycle carbon emission. Energy Policy 2010, 38, 1969-1978. [CrossRef]

55. Barbier, E. Geothermal energy technology and current status: An overview. Renew. Sustain. Energy Rev. 2002, 6, 63-65. [CrossRef]

56. Huttrer, G.W. The status of world geothermal power generation 1995-2000. Geothermics 2001, 30, 1-27. [CrossRef]

57. Koul, S.; Falebita, O.A.; Akinbami, J.F.K.; Akarakiri, J.B. System dynamics, uncertainty and hydrocarbon resources modelling: A systematic review. Renew. Sustain. Energy Rev. 2016, 59, 199-205. [CrossRef]

58. Sterman, J.D. Systems Thinking and Modeling for A Complex World; Business Dynamics; Irwin/McGraw-Hill: Boston, MA, USA, 2000.

59. Eker, S.; Van Daalen, C.E. Investigating the effects of uncertainties associated with the unconventional gas development in the Netherlands. In Proceedings of the 3 International Engineering Systems Symposium, CESUN2012, Delft, The Netherlands, 18-20 June 2012.

60. Richardson, G. Reflections on the foundations of system dynamics. Syst. Dyn. Rev. 2011, 27, $219-243$. [CrossRef]

61. Freeman, R.; Yearworth, M.; Cherruault, J.V. Review of Literature on Systems Thinking and System Dynamics for Policy Making; Department for Environment, Food and Rural Affairs: Bristol, UK, 2014.

62. Forrester, J.W. Information sources for modeling the national economy. J. Am. Stat. Assoc. 1980, 75, 555-566. [CrossRef]

63. Forrester, J.W. System dynamics-Future opportunities. Manag. Sci. 1980, 4, 7-21.

64. Elshorbagy, A.; Jutla, A.; Kells, J. Simulation of the hydro logical processes on reconstructed watersheds using system dynamics. Hydrol. Sci. J. 2007, 52, 53-61. [CrossRef]

65. Zhang, B.; Yuan, Y.-G. Theoretic and Experimental Thinking of Systematic Dynamics; China Environmental Science Press: Beijing, China, 2010; Volume 8, pp. 5-30.

66. Wang, T.-M. The Study on Fiscal and Taxation Policy of Natural Gas Industry in China. Ph.D. Thesis, China University of Petroleum, Beijing, China, 2013.

67. Tao, Z.-P. The Myth of Systematic Dynamics; China Environmental Science Press: Beijing, China, 2010; Volume 8, pp. 5-71.

68. Garcia, E.; Mohanty, A.; Lin, W.; Cherry, S. Dynamic analysis of hybrid energy systems under flexible operation and variable renewable generation-Part II: Dynamic cost analysis. Energy 2013, 52, 17-26. [CrossRef]

69. Santiago, M.; Luis, J.M.; Felipe, B. A system dynamics approach for the photo-voltaic energy market in Spain. Energy Policy 2013, 60, 142-154.

70. Liu, L.; Zong, H.; Zhao, E.; Cheng, C.; Wang, J. Can China realize its carbon emission reduction goal in 2020: From the perspective of thermal power development. Appl. Energy 2014, 124, 199-212. [CrossRef]

71. Zhao, X.; Ma, Q.; Yang, R. Factors influencing $\mathrm{CO}_{2}$ emissions in China's power industry: Co-integration analysis. Energy Policy 2013, 57, 89-98. [CrossRef]

72. Ali, K.; Mustafa, H. Exploring the options for carbon dioxide mitigation in Turkish electric power industry: System dynamics approach. Energy Policy 2013, 60, 675-686.

73. Feng, Y.; Chen, S.; Zhang, L. System dynamics modeling for urban energy consumption and $\mathrm{CO}_{2}$ emissions: A case study of Beijing, China. Ecol. Model. 2013, 252, 44-52. [CrossRef] 
74. Li, F.; Dong, S.; Li, Z.; Li, Y.; Li, S.; Wan, Y. The improvement of $\mathrm{CO}_{2}$ emission reduction policies based on system dynamics method in traditional industrial region with large $\mathrm{CO}_{2}$ emission. Energy Policy 2012, 51, 683-695. [CrossRef]

75. Nastaran, A.; Abbas, S. A system dynamics model for analyzing energy consumption and $\mathrm{CO}_{2}$ emission in Iranian cement industry under various production and export scenarios. Energy Policy 2013, 58, 75-89.

76. Guo, X.P.; Guo, X.D. Nuclear power development in China after the restart of new nuclear construction and approval: A system dynamics analysis. Renew. Sustain. Energy Rev. 2016, 57, 999-1007. [CrossRef]

77. Guo, X.P.; Guo, X.D. China's photovoltaic power development under policy incentives: A system dynamics analysis. Energy 2015, 93, 589-598. [CrossRef]

78. Seyed, H.H.; Hamed, S.G. A study on the future of unconventional oil development under different oil price scenarios: A system dynamics approach. Energy Policy 2016, 91, 64-74.

79. Salman, A.; Razman, M.T.; Firdaus, M.S.; Ruzairi, A.R. Application of system dynamics approach in electricity sector modelling: A review. Renew. Sustain. Energy Rev. 2016, 56, $29-37$.

80. Wu, X. The Reserch of Supporting and Encouraging Policies of Our Country's Geothermal Resource's Development and Utilization. Master's Thesis, China University of Geosciences, Wuhan, China, 2013.

81. Liu, N.-N. The fiscal support on development of shale gas industry. Tax. Res. 2014, 355, 21-24.

82. Li, B.-Q. Research of Financial Policy and Taxations to Promote Renewable Energy Development. Ph.D. Thesis; Ministry of Finance: Beijing, China, 2010.

(C) 2016 by the authors; licensee MDPI, Basel, Switzerland. This article is an open access article distributed under the terms and conditions of the Creative Commons Attribution (CC-BY) license (http://creativecommons.org/licenses/by/4.0/). 